\title{
TREE-RING DATING OF HISTORIC BUILDINGS IN WILLSBORO, NORTHEASTERN NEW YORK, AND DEVELOPMENT OF REGIONAL CHRONOLOGIES FOR DENDROARCHAEOLOGY
}

\author{
DAVID J. BARCLAY ${ }^{1 *}$ and JOHN A. RAYBURN ${ }^{2}$ \\ ${ }^{1}$ Geology Department, SUNY Cortland, Cortland, NY 13045, USA \\ ${ }^{2}$ Geology Department, SUNY New Paltz, New Paltz, NY 12561, USA
}

\begin{abstract}
Historical timbers have been sampled from buildings at 13 sites in Willsboro, New York, on the west shore of Lake Champlain. Ring-width series from 139 timbers have been successfully crossdated and used to develop tree-ring chronologies for ash (Fraxinus spp.), oak (Quercus spp.), pine (Pinus spp.), eastern hemlock (Tsuga canadensis (L.) Carr.), and spruce (Picea spp.), which collectively span A.D. 1555 to 1878 . Tree cutting dates suggest that Windyview Manor was likely built in or soon after 1799, and a barn and farmhouse at the 1812 Homestead were built in or soon after 1812 and 1813, respectively. These dates are all consistent with documentary records for these sites. Aggregate data for the town suggest a shift in wood use for building during the $19^{\text {th }}$ Century, with ash and oak commonly used for large frame timbers from the 1790 s to 1820 s, and hemlock and spruce dominating from the 1830 s to 1860 s. Chronologies developed in this project are among the first from historical timbers for northern New York and will facilitate further dendroarchaeological work in the region.
\end{abstract}

Keywords: tree rings, dendroarchaeology, New York, Adirondacks, Lake Champlain.

\section{INTRODUCTION}

Over recent decades there has been a slow increase of dendroarchaeological work in eastern North America (Stahle 1979; Robichaud and Laroque 2008; Grissino-Meyer 2009; Querrec et al. 2009). This region has a rich settlement history and such studies are important for dating structures and inferring wood-use behaviors of indigenous peoples, European colonizers, and American settlers. Old buildings are also a repository of tree-ring samples from the original pre-clearance forests and so enable extension of living tree-ring chronologies for dendroclimatic reconstructions (e.g. Pederson et al. 2013).

In New York State, dendroarchaeological work can be challenging for several reasons. Forest clearance in the $18^{\text {th }}$ and $19^{\text {th }}$ Centuries exceeded $80 \%$ in some areas (Glitzenstein et al. 1990; Smith et al. 1993; McMartin 1994), and so there are relatively few living tree-ring chronolo-

*Corresponding author: david.barclay@cortland.edu gies long enough or located close enough for crossdating with samples from old buildings. The species diversity and varied ecological niches of trees in New York (Edinger et al. 2002) also means that historical buildings may contain wood from a range of species and from growth settings dissimilar to the available master chronologies. Nonetheless, the potential for dendroarchaeological work in New York is demonstrated by a number of successful building and site studies, mostly in the Hudson Valley in the southeast part of the state (Harvey 2012; see also reports at http://hvva. net/dendro.html).

In this paper we present the initial results from dendroarchaeological work in Willsboro in northeastern New York (Figure 1). Since 2008 we have sampled historical structures at 13 sites in this town with the goal of dating buildings and better understanding the local settlement history. Here we detail development of seven tree-ring chronologies for Willsboro and present results from structures at two of the oldest sites studied thus far, the 1812 Homestead and Windyview Manor. 


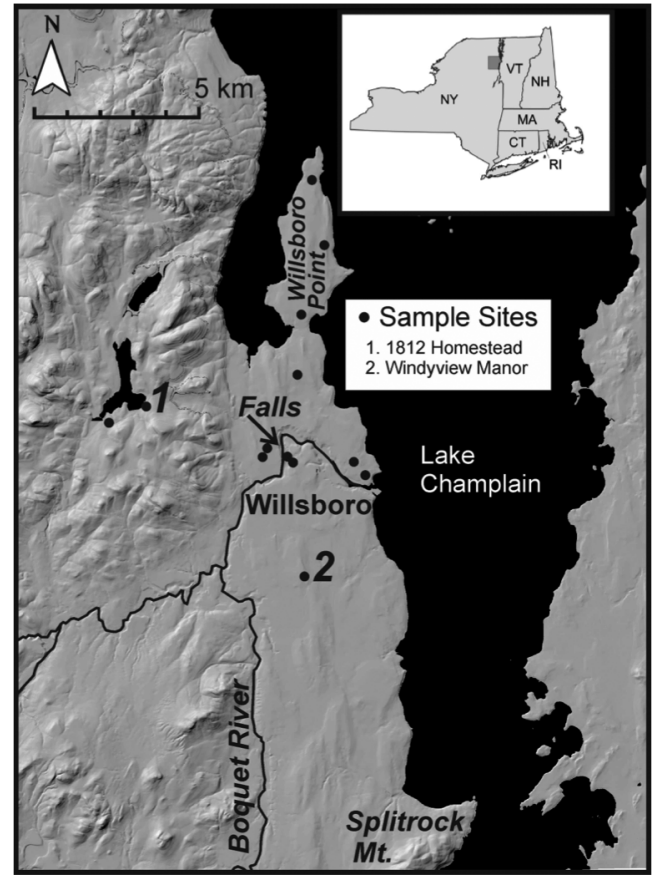

Figure 1. Hillshade map of study area. Black dots are sample sites in and around Willsboro.

\section{SETTING}

Willsboro is located on the west shore of Lake Champlain (Figure 1). Pleistocene-age glacial, glacilacustrine, and glacimarine sediments over early Paleozoic sedimentary rocks fringe the lakeshore, while the Adirondack upland to the west is formed of Precambrian igneous and metamorphic rocks (Buddington and Whitcomb 1941). Mountain peaks immediately west of Willsboro reach up to $501 \mathrm{~m}$ above sea level whereas the Willsboro lowlands range in elevation from about $120 \mathrm{~m}$ down to the surface of Lake Champlain at $30 \mathrm{~m}$. The Boquet River (Figure 1) is about $64 \mathrm{~km}$ long and drains from the High Peaks area of the Adirondacks. Climate is characterized by warm summers and cold snowy winters with Burlington, $22 \mathrm{~km}$ to the northeast in Vermont on the east shore of Lake Champlain, recording monthly average temperatures of $-8^{\circ} \mathrm{C}$ in January, $21^{\circ} \mathrm{C}$ in July, and total annual precipitation of $914 \mathrm{~mm}$ (1981-2010 NCDC normals).

Terrestrial ecosystems around Willsboro are predominantly classified as Laurentian-Acadian
Pine-Hemlock-Hardwood and Northern Pine (Oak) forests (Sayre et al. 2009). The earliest land surveys of the area between the mouth of the Boquet River and Split Rock Mountain (Figure 1) were done in A.D. 1765-1766 and suggest that the pre-clearance forest of the Willsboro lowland was dominated by pine, with 46 of the 101 trees identified in the lotting surveys being pine and one area being described as a pinery (Watson 1863). Other witness tree taxa named between three and eight times in these lotting surveys were ash, beech, birch, cedar, elm, hemlock, hickory, maple, oak, and poplar. Modern maps indicate that there are about 50 different species of medium to large trees native to the Willsboro area (Little 1971, 1980), which potentially could have been used as building timbers.

Lake Champlain and its fringing lowlands have historically formed the primary travel route between the Hudson and Saint Lawrence valleys, but the Willsboro area remained largely unsettled during most of the pre-Columbian and Colonial eras (Palmer 1983). Permanent settlement began after the French and Indian War with arrival in 1765 of a small group of pioneers led by William Gilliland, an Irish immigrant and war veteran who had purchased grants for lands along the lakeshore (Watson 1863). Homesteading and forest clearance initially focused on the area around the mouth of the Boquet River and south to Split Rock Mountain (Figure 1). However, the growing settlement was abandoned in the American Revolutionary War, during which the pioneer homesteads were looted and razed by armies, raiding parties, and war refugees (Watson 1863).

Re-settlement began in 1784 and the community center grew at the falls of the Boquet River (Figure 1), an area where Gilliland had previously built grist and saw mills and which was formerly known as Milltown. Population, land clearance, and farming increased throughout the $19^{\text {th }}$ Century and expanded to Willsboro Point and into lower areas of the adjacent upland (Tefft 1997). The 1812 Homestead is located on the edge of the upland along the original main road leading north to Plattsburgh and Canada, and includes a farmhouse (Figure 2A), a barn (Figure 2B), and a small wood shop. Windyview Manor is south of 


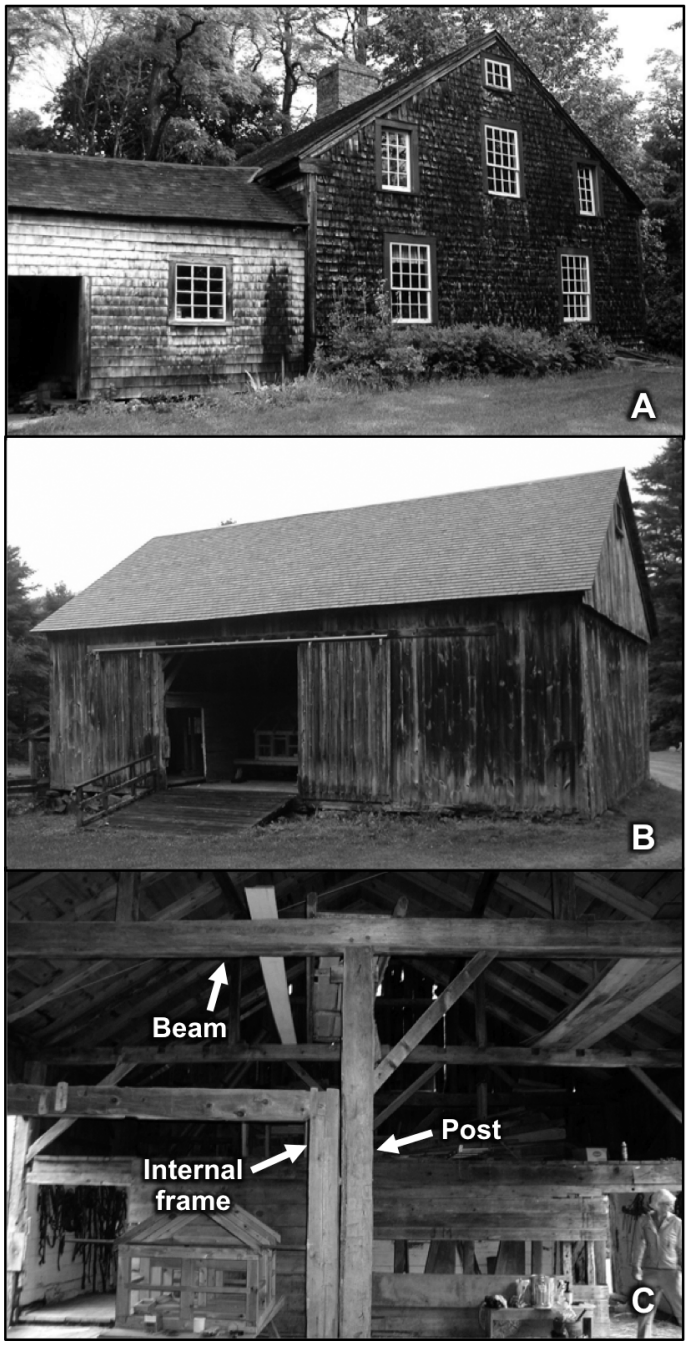

Figure 2. 1812 Homestead farmhouse (A), barn exterior (B) and barn interior $(\mathrm{C})$.

the Boquet falls on Middle Road, a local road to farms on the lowland, and is comprised of a main house (Figure 3A) and an attached annex.

\section{METHODS}

\section{Sample Collection and Preparation}

Our general sampling strategy for each building in Willsboro was to core original frame timbers that were likely to have at least 50 rings and, whenever possible, also had bark or a waney edge. In the open interiors of barns (Figure 2C) we were usually able to core all the major vertical

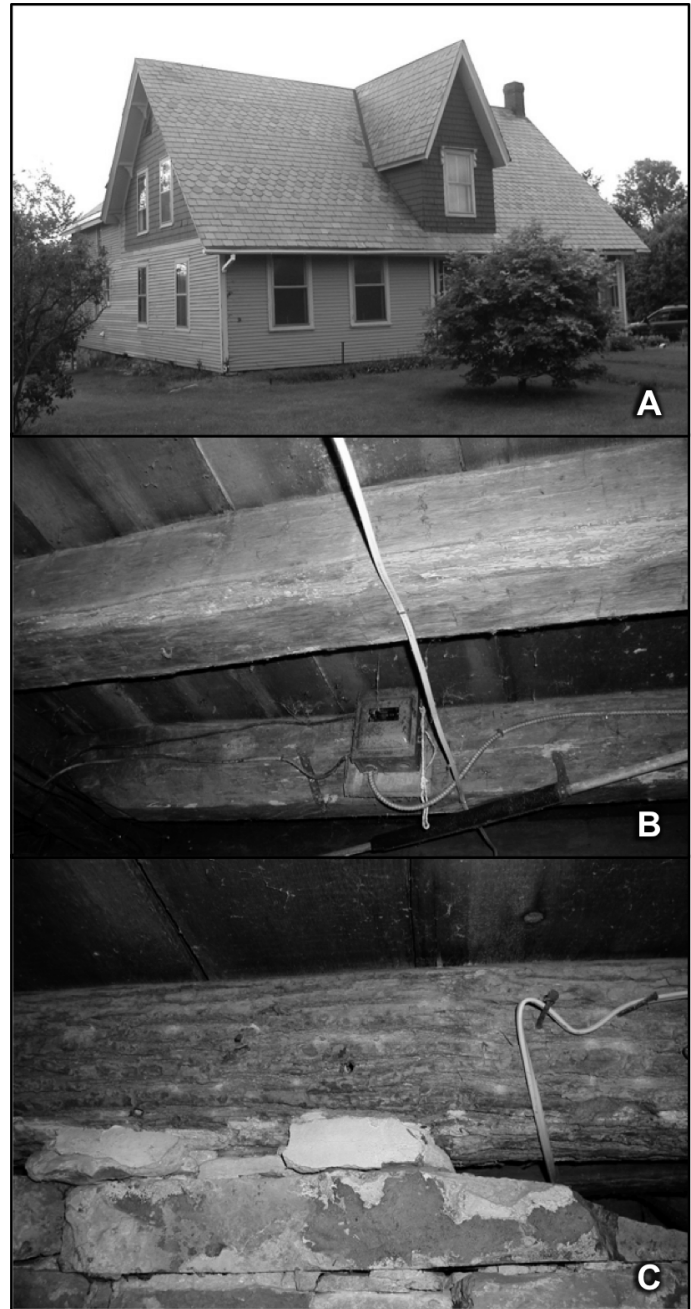

Figure 3. Windyview Manor main house exterior (A), squarecut beams in ceiling of main house cellar (B) and round beam with bark in ceiling of annex cellar (C).

timbers (posts) and many of the major horizontal timbers (beams, girts, plates, and sills). Haylofts provided access to upper areas of most barns and additional samples were sometimes taken from smaller timbers (joists, studs, purlins, and rafters). Sampling was more limited in other structures (houses, annexes, additions, a cabin, and a church) because of frame timbers being hidden by external siding, and internal paneling, plastering, and flooring. Basements and attics were often the only places where frame timbers could be accessed. Our samples for 2008 to 2011 averaged 15 timbers per barn (minimum three, maximum 26) and six 
timbers (minimum one, maximum 15) in other structures.

Sampling was done using a 5.15-mm-diameter increment borer. Cores were collected through bark, a waney edge, or the corner of square-cut timbers whenever possible, and most timbers were cored one or two times depending on timber exposure, wood quality, and safety considerations. Core holes were digitally photographed and notes made on the likely preservation of outer rings, both at the core position and elsewhere along the timber.

In the lab the samples were air-dried, glued into holders, and sanded with increasingly fine sand papers (up to 1500 grit for some samples) to reveal wood cells and structures on the crosssectional surface. Tree taxa were identified to the genus level based on microscopic examination of the prepared cross-sectional surface using keys in Brown et al. (1949) and Hoadley (1990), and by comparison with reference samples collected from living trees around the Willsboro area. Photographs of bark were also used to aid identification of some samples with reference to Little (1980).

\section{Crossdating}

Crossdating began with pairs of cores of the same genus, often from the same timber, under a binocular microscope. Each core was visually matched to the other based on annual ring widths and earlywood and latewood appearance, and the tenth, fiftieth, and hundredth rings marked with respectively one, two or three dots (Stokes and Smiley 1968). This marking began with an assumed starting year on one of the cores being crossdated. Annual ring widths were measured digitally to the nearest $0.001 \mathrm{~mm}$ using a Velmex linear encoder system and PJK software (P. Krusic, unpublished), and on-screen line graphs showing the ring width patterns over decades (Baillie 1982) were used to assist the on-core crossdating. This process progressed through the paired cores until all problem sections (e.g. false rings, missing rings, condensed growth, ring offsets along rays, gaps caused by breaks, woodworm, and decay) were resolved and the samples were visually crossdated relative to each other throughout.
The COFECHA program (Holmes 1983) was used to statistically check crossdates. To enhance the time-series characteristics important to crossdating, each measured ring width series was standardized using a spline with a 50\% frequency response of 32 years, persistence removed by autoregressive modeling, and each series logtransformed (Grissino-Mayer 2001). Series were then tested against the COFECHA master chronology in 50-year segments offset by 25 years. Segments that did not correlate at or above the 99\% one-tailed confidence level (CL), or which correlated better with a systematic offset of one to a few years in successive 50-year segments, were re-examined visually to identify and resolve the crossdating problem. Samples were accepted as correctly crossdated if all or most of the successive 50 -year segments correlated at or above the $99 \%$ $\mathrm{CL}$ and if the crossdate was visually convincing.

Chronology development proceeded with crossdating of paired samples to other samples of the same genus from timbers in the same building, and then with samples of the same genus from elsewhere in Willsboro. COFECHA was used to suggest crossdate positions, crossdates were confirmed by visual inspection with line graphs and on the cores, and crossdating problems resolved as the chronologies grew. Our goal was to develop chronologies that had a strong common signal and this led to multiple chronologies being developed for some genera that subdivided into distinct populations based on their crossdating characteristics. The resulting floating chronologies (i.e. internally crossdated but not calendar-dated by linkage to living trees) were checked with COFECHA to ensure that all component series correlated with the COFECHA master at or above the $99 \%$ CL for the full series lengths, and that all or most 50-year segments also correlated at or above the $99 \%$ CL.

\section{Final Chronologies and Outer Ring Dates}

The Willsboro floating chronologies were calendar-dated by crossdating with each other and with master chronologies from northern, eastern, and central New York. COFECHA was used to identify crossdate positions based on offset 
50-year segments, and crossdates were confirmed visually with line graphs and statistically with correlations based on the full periods of overlap. Dates of the component ring-width series were then updated to reflect the final chronology calendar dates.

The outermost rings of all calendar crossdated samples were re-examined carefully to confirm the last year of growth. Only complete annual rings had been measured and so any earlywood or latewood of a partial growth ring beyond the last measured ring was noted. Core hole photographs, field notes, and the core samples were also reviewed to check for the presence of bark or a waney edge. First and last year dates were determined for each timber based on all available cores and with partial growth years included. Distorted or badly damaged rings had also been avoided during measurement, but are included in the first and last year dates in cases where they could be counted with confidence. Using a modified form of a scheme proposed by Baillie (1982), the quality of the outermost ring dates of all crossdated timbers were rated as follows:

$A_{e}$ or $A_{1}$ Precise date. Bark or a waney edge present and last ring date is the actual last year of growth. Subscript indicates that the last ring ends with earlywood (e) or latewood (1).

B Close date. Quality of outer rings and consilience with other samples suggests that date is within a few years of when the tree died.

C Minimum date. No clear indication that the last ring date is close to the actual death date of the tree, so date simply constrains the year of tree death to be sometime after the last year of recorded growth.

D Suspect. Outer rings known to be lost, removed, badly decayed, or damaged.

\section{RESULTS}

\section{Willsboro Chronologies}

A total of 139 timbers have been successfully crossdated and assigned calendar dates (Table 1).
Table 1. Sampled taxa and crossdating success.

\begin{tabular}{lccc}
\hline \multicolumn{1}{c}{ Genus } & $\begin{array}{c}\text { No. Timbers } \\
\text { Sampled }\end{array}$ & $\begin{array}{c}\text { No. Timbers } \\
\text { Crossdated }\end{array}$ & $\begin{array}{c}\text { Success } \\
\text { Rate }(\%)^{1}\end{array}$ \\
\hline Ash (Fraxinus spp.) & 27 & 17 & 71 \\
Oak (Quercus spp.) & 27 & 25 & 100 \\
Birch (Betula spp.) & 9 & 0 & - \\
Maple (Acer spp.) & 3 & 0 & - \\
Elm (Ulmus spp.) & 3 & 0 & - \\
Cherry (Prunus sp.) & 2 & 0 & - \\
Hickory (Carya spp.) & 1 & 0 & - \\
Pine (Pinus spp.) & 73 & 34 & 87 \\
Hemlock (Tsuga sp.) & 43 & 40 & 100 \\
Spruce (Picea spp.) & 24 & 23 & 100 \\
Cedar (Thuja sp.) & 1 & 0 & - \\
Totals & 213 & 139 & - \\
\hline
\end{tabular}

${ }^{1}$ After exclusion of short ( $<60$ rings) and broken samples.

These samples have been used to develop tree-ring chronologies for ash (Fraxinus spp.), oak (Quercus spp.), pine (Pinus spp.), eastern hemlock (Tsuga canadensis (L.) Carr.), and spruce (Picea spp.) (Table 2, Figure 4). An additional six tree genera have been found during sampling (Table 1) but in too few numbers to enable chronology development.

All seven of the Willsboro chronologies correlate well $(\mathrm{p}<0.001)$ with master chronologies from New York (Table 2, Figure 4). One of these masters is a composite chronology of historical oak timbers from central and northern New York (CNQUSP), while the others are living tree chronologies from $40 \mathrm{~km}$ to the west of Willsboro in the Adirondack Mountains (WNPIST, WPPIST, RBTSCA, and RBPCRU) and 145 to $165 \mathrm{~km}$ to the south-southeast of Willsboro in the northern Hudson Valley (PMQUAL and GEQUMT). All of these chronology crossdates are between trees of the same genus, except WHFR1-to-GEQUMT that is between ash and chestnut oak (Quercus montana Willd.).

Most of the Willsboro chronologies also correlate well with each other (Table 3). The groupings of WHFR1-WHQU1-WHPI and WHPI1-WHTS1-WHPC1 in particular show consistently strong $(p<0.001)$ inter-relationships, suggesting common responses to climate in their growth signals. The weaker correlations involve 
Table 2. Willsboro tree-ring chronologies.

\begin{tabular}{llccccccc}
\hline $\begin{array}{c}\text { Willsboro } \\
\text { Chronology }\end{array}$ & Genus & Interval & $\begin{array}{c}\text { No. of } \\
\text { Timbers }\end{array}$ & $\begin{array}{c}\text { No. of } \\
\text { Series }\end{array}$ & $\begin{array}{c}\text { Mean } \\
\text { Correlation }\end{array}$ & $\begin{array}{c}\text { Mean } \\
\text { Sensitivity }\end{array}$ & $\begin{array}{c}\text { Linked } \\
\text { Chronology }^{2}\end{array}$ & Correlation $^{3}$ \\
\hline WHFR1 & Ash & $1654-1822$ & 17 & 23 & 0.428 & 0.185 & GEQUMT & $0.339(157)$ \\
WHQU1 & Oak & $1555-1811$ & 6 & 12 & 0.573 & 0.207 & PMQUAL & $0.370(123)$ \\
WHQU2 & Oak & $1557-1798$ & 19 & 40 & 0.477 & 0.175 & CNQUSP & $0.434(190)$ \\
WHPI1 & Pine & $1619-1848$ & 29 & 45 & 0.551 & 0.230 & WNPIST & $0.430(217)$ \\
WHPI2 & Pine & $1655-1851$ & 5 & 7 & 0.528 & 0.312 & WPPIST & $0.345(156)$ \\
WHTS1 & Hemlock & $1704-1877$ & 40 & 47 & 0.565 & 0.221 & RBTSCA & $0.608(174)$ \\
WHPC1 & Spruce & $1635-1848$ & 23 & 32 & 0.517 & 0.205 & RBPCRU & $0.553(214)$ \\
\hline
\end{tabular}

${ }^{1}$ Statistics for COFECHA master chronology.

${ }^{2}$ Master chronology to which each Willsboro chronology correlates most strongly. GEQUMT: Goose Egg Ridge chestnut oak, Pederson et al. 2013, ITRDB NY017; PMQUAL, Prospect Mountain white oak, Pederson et al. 2013, ITRDB NY035; CNQUSP: central New York historical oak, C. B. Griggs, unpublished data; WNPIST: Wilmington Notch Roaring Brook eastern white pine, E.R. Cook, ITRDB NY013; WPPIST: Winch Pond Adirondack Mountains eastern white pine, E.R. Cook, ITRDB NY014; RBTSCA: Roaring Brook Keene Valley eastern hemlock, E.R. Cook, ITRDB NY009; RBPCRU, Roaring Brook Keene Valley red spruce, E.R. Cook, ITRDB NY010.

${ }^{3}$ Correlation with master chronology, number of overlap years in parentheses. All significant at $\mathrm{p}<0.001$.

one or both of WHQU2 and WHPI2, which may reflect the trees comprising these two chronologies coming from settings where the factors limiting growth were somewhat different to trees in the other chronologies.

\section{Homestead}

Intact samples were collected from seven large beams exposed in the cellar ceiling of the 1812 Homestead farmhouse (Figure 2A). All were ash and three were too broken or short to crossdate (Table 4). The remaining four cellar beam samples had outer ring dates of 1739,1778 , 1790 , and 1811, but the poor quality of the outermost wood and lack of bark in the samples means that these are not true felling dates of the original trees. Much better quality samples were obtained from two pine beams exposed in the farmhouse attic. Both had latewood for 1812, no earlywood for 1813, and intact bark, indicating that they were cut at the end of or after the 1812 growing-season and before the 1813 growingseason. The two attic beams were identified as red pine (Pinus resinosa Ait.) on the basis of bark on the timbers, wood hardness, and the abrupt onset and strong color of the latewood.

Nineteen posts and beams were sampled in the adjacent barn (Figure 2B and 2C). Eleven of the ash, oak, and pine timbers had latewood for
1811, no earlywood for 1812 , and bark or a waney edge (Table 4). All but one of the last ring dates of the other samples range from 1769 to 1809 and, when considered with the 11 samples with precise outer ring dates, these data are consistent with the trees being felled at the end of or after the 1811 growing-season and before the 1812 growingseason. The one exception is a pine timber that has a last ring date of 1828 , but this was clearly an internal frame (Figure 2C) added to the barn after it was built. Furrowed bark on four of the ash timbers suggests that they were white ash (Fraxinus americana $\mathrm{L}$.) or green ash ( $F$. pennsylvanica Marsh.), while numerous small latewood pores and scaly bark on two of the oak posts suggests that they were white oak (Quercus alba L.). Local abundance and large size make eastern white pine (Pinus strobus L.) or red pine the most likely species for the pine posts and beams.

A total of 12 timbers were sampled from the 1812 Homestead wood shop, a separate small structure close to the farmhouse and barn. Nine of these were identified as pine (probably eastern white pine) and three as birch (Betula spp.). However, none of the samples had more than 40 rings and so none could be crossdated. Annual rings of these samples show fast and even growth, suggesting that these trees grew in an unstressed environment such as an open canopy setting with plentiful water. 

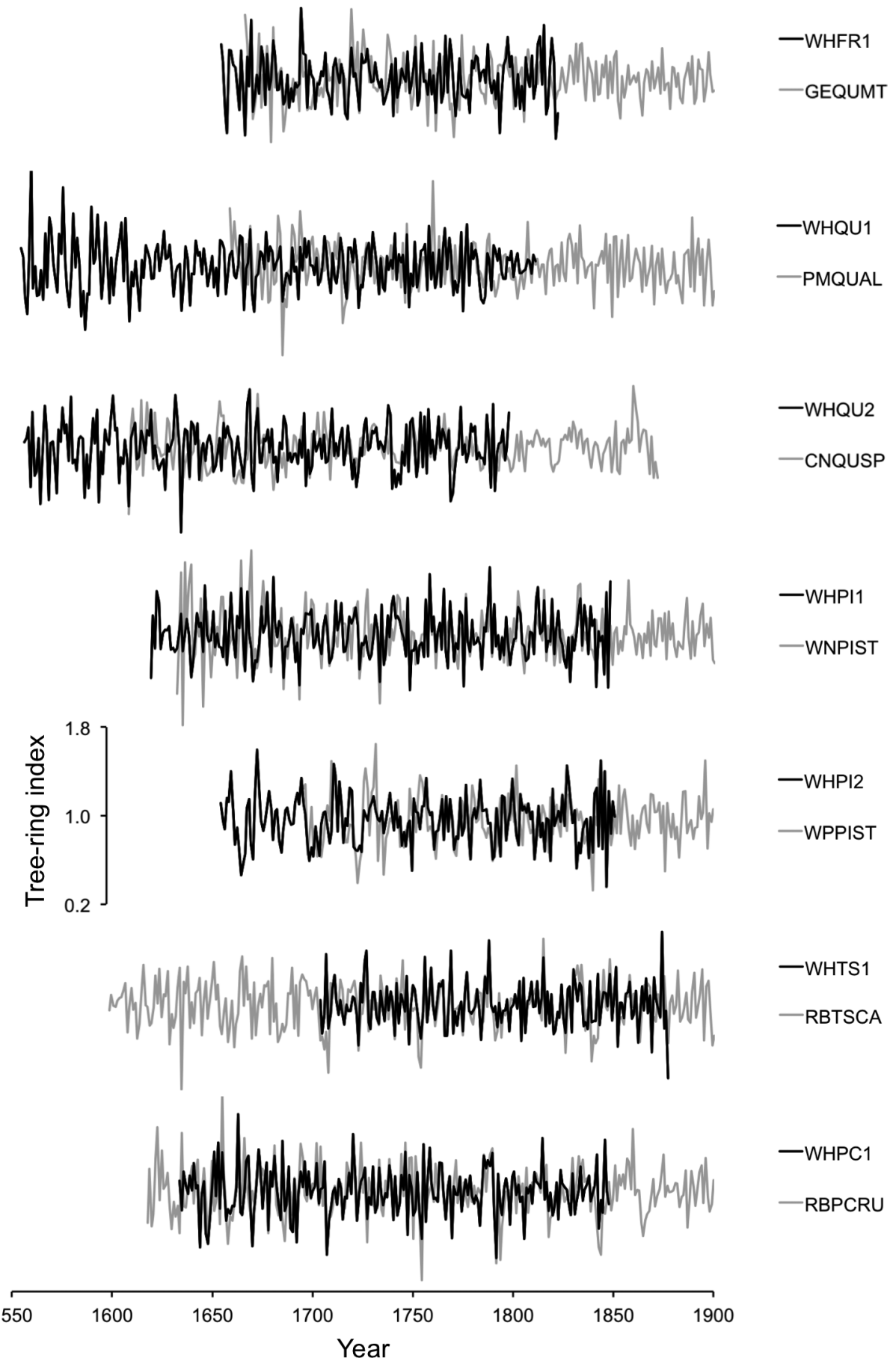

Figure 4. Tree-ring chronologies for Willsboro (black) and regional master chronologies (grey) with which they are crossdated. All chronologies have been detrended with flexible splines and prewhitened to remove persistence. See Table 2 for explanation of labels. All plots have same vertical scale. 
Table 3. Correlation (upper right) and overlap years (lower left) of Willsboro chronologies.

\begin{tabular}{lccccccc}
\hline & WHFR1 & WHQU1 & WHQU2 & WHPI1 & WHPI2 & WHTS1 & WHPC1 \\
\hline WHFR1 & & $0.480^{* * *}$ & $0.316^{* * *}$ & $0.322^{* * *}$ & $0.172^{*}$ & $0.199^{*}$ & $0.146^{*}$ \\
WHQU1 & 156 & & $0.229^{* * *}$ & $0.539^{* * *}$ & 0.129 & $0.278^{* *}$ & $0.287^{* * *}$ \\
WHQU2 & 143 & 240 & $0.182^{* *}$ & 0.134 & 0.149 & $0.193^{* *}$ \\
WHPI1 & 167 & 191 & 178 & & 0.014 & $0.443^{* * *}$ & $0.434^{* * *}$ \\
WHPI2 & 166 & 155 & 142 & 192 & & 0.106 & 0.021 \\
WHTS1 & 117 & 106 & 93 & 143 & 146 & & $0.602^{* * *}$ \\
WHPC1 & 167 & 175 & 162 & 212 & 192 & 143 & \\
\hline
\end{tabular}

Significance level of correlations: ${ }^{*} \mathrm{p}<0.05,{ }^{* *} \mathrm{p}<0.01,{ }^{* * *} \mathrm{p}<0.001$.

Table 4. Sample results for 1812 Homestead.

\begin{tabular}{|c|c|c|c|c|c|c|c|c|}
\hline $\begin{array}{l}\text { Sample } \\
\text { Number }\end{array}$ & Description & Genus & $\begin{array}{l}\text { First } \\
\text { Year }\end{array}$ & $\begin{array}{l}\text { Last } \\
\text { Year }\end{array}$ & $\begin{array}{l}\text { Outer } \\
\text { Ring }^{1}\end{array}$ & $\begin{array}{l}\text { Willsboro } \\
\text { Chronology }\end{array}$ & \multicolumn{2}{|c|}{$\begin{array}{l}\text { Correlation of Series with } \\
\text { Willsboro Chronology }\end{array}$} \\
\hline \multicolumn{9}{|c|}{1812 Homestead farmhouse: } \\
\hline W01A & Cellar beam & Ash & & & & & & \\
\hline W01B & Cellar beam & Ash & & & & & & \\
\hline W01C & Cellar beam & Ash & 1675 & 1739 & $\mathrm{D}$ & WHFR 1 & $0.533(63)$ & \\
\hline W01D & Cellar beam & Ash & 1660 & 1778 & $\mathrm{D}$ & WHFR1 & $0.327(95)$ & \\
\hline W01E & Cellar beam & Ash & & & & & & \\
\hline W01F & Cellar beam & Ash & 1684 & 1811 & $\mathrm{~B}$ & WHFR1 & $0.455(118)$ & $0.310(62)$ \\
\hline W01G & Cellar beam & Ash & 1673 & 1790 & $\mathrm{C}$ & WHFR 1 & $0.644(114)$ & $0.486(66)$ \\
\hline W01H & Cellar beam & Ash & & & & & & \\
\hline W01I & Attic beam & Pine & 1751 & 1812 & $\mathrm{~A}_{1}$ & WHPI1 & $0.529(61)$ & \\
\hline W01J & Attic beam & Pine & 1712 & 1812 & $\mathrm{~A}_{1}$ & WHPI1 & $0.580(100)$ & \\
\hline \multicolumn{9}{|c|}{1812 Homestead barn: } \\
\hline W20A & Post (center) & Ash & 1710 & 1811 & $\mathrm{~A}_{1}$ & WHFR 1 & $0.520(101)$ & $0.549(93)$ \\
\hline W20B & Internal frame & Pine & 1751 & 1828 & $\mathrm{C}$ & WHPI1 & $0.694(76)$ & \\
\hline W20C & Post (door) & Oak & 1607 & 1808 & $\mathrm{~B}$ & WHQU1 & $0.656(186)$ & 0.651 (191) \\
\hline W20D & Post (corner) & Pine & & & & & & \\
\hline W20E & Post (wall) & Ash & 1689 & 1811 & $\mathrm{~A}_{1}$ & WHFR1 & 0.460 (114) & $0.580(122)$ \\
\hline W20F & Post (door) & Oak & 1620 & 1811 & $\mathrm{~A}_{1}$ & WHQU1 & $0.699(191)$ & $0.683(174)$ \\
\hline W20G & Post (door) & Oak & 1631 & 1811 & $\mathrm{~A}_{1}$ & WHQU1 & 0.545 (139) & 0.726 (179) \\
\hline $\mathrm{W} 20 \mathrm{H}$ & Post (corner) & Pine & 1625 & 1803 & $\mathrm{C}$ & WHPI1 & $0.627(177)$ & \\
\hline W20I & Post (wall) & Pine & 1644 & 1809 & $\mathrm{~B}$ & WHPI1 & $0.504(164)$ & $0.581(100)$ \\
\hline W20J & Post (corner) & Pine & 1636 & 1769 & $\mathrm{C}$ & WHPI1 & $0.660(132)$ & $0.573(100)$ \\
\hline W20K & Post (door) & Oak & 1622 & 1811 & $A_{1}$ & WHQU1 & $0.615(188)$ & \\
\hline W20L & Post (center) & Ash & 1697 & 1811 & $\mathrm{~A}_{1}$ & WHFR 1 & 0.507 (114) & \\
\hline W20M & Beam (wall) & Pine & 1646 & 1811 & $\mathrm{~A}_{1}$ & WHPI1 & $0.646(151)$ & $0.695(72)$ \\
\hline $\mathrm{W} 20 \mathrm{~N}$ & Beam (center) & Pine & 1734 & 1811 & $A_{1}$ & WHPI1 & $0.359(54)$ & 0.407 (64) \\
\hline W20O & Beam (wall) & Maple? & & & & & & \\
\hline W20P & Beam (wall) & Ash & 1653 & 1811 & $\mathrm{~A}_{1}$ & WHFR 1 & $0.316(158)$ & \\
\hline W20Q & Beam (wall) & Maple? & & & & & & \\
\hline W20R & Beam (wall) & Ash & 1721 & 1811 & $\mathrm{~A}_{1}$ & WHFR 1 & $0.578(90)$ & \\
\hline W20S & Beam (wall) & Ash & 1653 & 1811 & $\mathrm{~A}_{1}$ & WHFR1 & $0.407(158)$ & \\
\hline
\end{tabular}

${ }^{1}$ See Methods for definition of codes.

${ }^{2}$ Overlap years in parentheses. All significant at or above the $99 \%$ confidence level in one-tailed t-test. 
Table 5. Sample results for Windyview.

\begin{tabular}{|c|c|c|c|c|c|c|c|c|}
\hline $\begin{array}{l}\text { Sample } \\
\text { Number }\end{array}$ & Description & Genus & First Year & $\begin{array}{l}\text { Last } \\
\text { Year }\end{array}$ & $\begin{array}{l}\text { Outer } \\
\text { Ring }^{1}\end{array}$ & $\begin{array}{l}\text { Willsboro } \\
\text { Chronology }\end{array}$ & \multicolumn{2}{|c|}{$\begin{array}{l}\text { Correlation of Series with } \\
\text { Willsboro Chronology }\end{array}$} \\
\hline \multicolumn{9}{|c|}{ Windyview Manor main house: } \\
\hline W06A & Cellar beam & Oak & & & & & & \\
\hline W06B & Cellar beam & Pine & & & & & & \\
\hline W06C & Cellar beam & Oak & 1605 & 1798 & $A_{1}$ & WHQU2 & $0.483(152)$ & $0.498(181)$ \\
\hline W06D & Cellar beam & Oak & 1648 & 1798 & $\mathrm{~A}_{1}$ & WHQU2 & $0.445(150)$ & $0.552(134)$ \\
\hline W06E & Cellar beam & Oak & 1659 & 1789 & $\mathrm{C}$ & WHQU2 & $0.691(115)$ & $0.604(127)$ \\
\hline W06F & Cellar beam & Oak & 1672 & 1798 & $\mathrm{~A}_{1}$ & WHQU2 & $0.514(122)$ & $0.378(113)$ \\
\hline W06I & Cellar beam & Oak & 1595 & 1794 & $\mathrm{~B}$ & WHQU2 & $0.599(198)$ & $0.533(55)$ \\
\hline W06J & Cellar beam & Oak & 1587 & 1795 & $\mathrm{~B}$ & WHQU2 & $0.474(207)$ & $0.426(38)$ \\
\hline W06K & Cellar beam & Oak & 1599 & 1794 & B & WHQU2 & $0.453(128)$ & $0.360(156)$ \\
\hline W06L & Cellar beam & Oak & 1646 & 1796 & B & WHQU2 & $0.461(149)$ & $0.404(122)$ \\
\hline W06M & Cellar beam & Oak & 1567 & 1739 & $\mathrm{C}$ & WHQU2 & $0.333(164)$ & $0.456(152)$ \\
\hline $\mathrm{W} 06 \mathrm{~N}$ & Cellar beam & Oak & 1556 & 1772 & $\mathrm{C}$ & WHQU2 & $0.293(214)$ & $0.369(172)$ \\
\hline W06O & Cellar beam & Oak & 1679 & 1798 & $A_{1}$ & WHQU2 & $0.515(119)$ & $0.618(118)$ \\
\hline \multicolumn{9}{|c|}{ Windyview Manor annex - south side: } \\
\hline W06H & Cellar beam & Oak & 1717 & 1788 & $\mathrm{C}$ & WHQU2 & $0.536(63)$ & $0.573(64)$ \\
\hline W06P & Cellar beam & Oak & 1718 & 1789 & $\mathrm{C}$ & WHQU2 & $0.553(70)$ & \\
\hline W06Q & Cellar beam & Oak & 1703 & 1797 & $\mathrm{~B}$ & WHQU2 & $0.515(78)$ & $0.532(83)$ \\
\hline W06R & Cellar beam & Oak & 1704 & 1791 & $\mathrm{~B}$ & WHQU2 & $0.429(84)$ & $0.451(79)$ \\
\hline W06U & Cellar beam & Oak & 1589 & 1775 & $\mathrm{C}$ & WHQU2 & $0.412(155)$ & $0.310(173)$ \\
\hline W06Z & Cellar beam & Oak & 1690 & 1796 & $\mathrm{~B}$ & WHQU2 & $0.545(95)$ & $0.442(95)$ \\
\hline \multicolumn{9}{|c|}{ Windyview Manor annex - north side: } \\
\hline W06G & Cellar beam & Hemlock & 1729 & 1847 & B & WHTS1 & $0.552(117)$ & $0.627(101)$ \\
\hline W06S & Cellar beam & Pine & & & & & & \\
\hline W06T & Cellar beam & Pine & 1703 & 1852 & $\mathrm{~A}_{\mathrm{e}}$ & WHPI2 & 0.461 (148) & $0.531(66)$ \\
\hline W06V & Cellar beam & Pine & 1683 & 1852 & $A_{e}$ & WHPI2 & $0.623(168)$ & \\
\hline W06W & Cellar beam & Pine & 1654 & 1852 & $\mathrm{~A}_{1}$ & WHPI2 & $0.530(197)$ & \\
\hline W06X & Cellar beam & Pine & 1659 & 1852 & $A_{e}$ & WHPI2 & $0.463(192)$ & \\
\hline W06Y & Cellar beam & Pine & 1673 & 1852 & $\mathrm{~A}_{\mathrm{e}}$ & WHPI2 & $0.498(178)$ & $0.668(83)$ \\
\hline
\end{tabular}

${ }^{1}$ See Methods for definition of codes.

${ }^{2}$ Overlap years in parentheses. All significant at or above the $99 \%$ confidence level in one-tailed t-test.

\section{Windyview Manor}

Thirteen beams exposed in the cellar ceiling of the main house (Figure 3A) at Windyview Manor were sampled. One of these was a pine that did not crossdate, whereas the other 12 were large (20-30 cm wide), mostly square-cut beams of oak (Figure 3B). Four of these had latewood for 1798 and then bark, while outer rings of the other eight beams were less well preserved and had outer ring dates ranging from 1739 to 1796 (Table 5). These data are consistent with the trees being felled at the end of or after the 1798 growing-season and before the 1799 growing-season. All of the oak samples had small and numerous latewood pores indicative of the white oak group (Quercus Sect. Leucobalanus), and the four beams with bark were identified as probably swamp white oak ( $Q$. bicolor Willd.).

Six beams in the cellar ceiling of the adjacent annex were also identified as being of the white oak group and, based on bark found on five (Figure 3C), were also probably swamp white oak. However, outer rings beneath the bark had decayed and last year dates ranged from 1775 to 1797 (Table 5). These six beams were all in the southern half of the annex and appear to be all or part of a structure that was built using wood cut at the same time as the timbers used for the main house. 


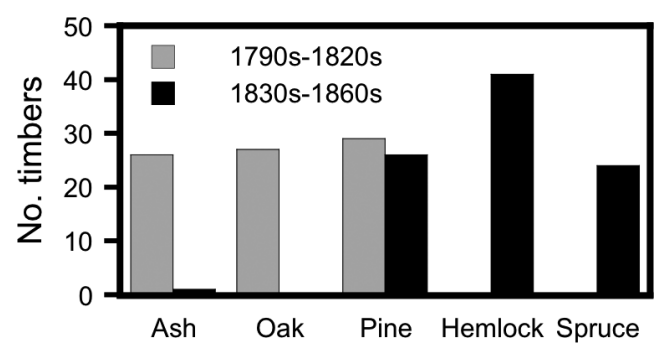

Figure 5. Timber usage in the $1790 \mathrm{~s}-1820 \mathrm{~s}$ and $1830 \mathrm{~s}-1860 \mathrm{~s}$ in Willsboro. Data are for the five most commonly sampled genera $(\mathrm{n}=174)$.

Seven beams were sampled from the cellar ceiling of the northern half of the annex, and these were respectively identified as an eastern hemlock and six pine. The hemlock had a last ring date of 1847 but no bark, and one pine did not crossdate (Table 5). Four of the other pine ended with earlywood for 1852 beneath bark or a waney edge, whereas the last had a little latewood for 1852 and then bark. These results suggest that the pine were felled during the growing season of 1852, and that the northern half of the annex was built using trees cut more recently than the trees in the southern half. Based on the bark and the abrupt onset of latewood, the five crossdated pine beams were all probably red pine.

\section{DISCUSSION AND CONCLUSIONS}

\section{Building Dates and Wood Use}

Winter and early spring were the usual times for cutting large trees in the Willsboro region in the $18^{\text {th }}$ and $19^{\text {th }}$ Centuries because the logs could be moved relatively easily on sleds over the snowcovered landscape (Watson 1863; Keller 1980). This documented practice is consistent with our tree-ring results with almost all of the precise last year dates at the 1812 Homestead farmhouse and barn and Windyview Manor indicating tree death between two growing seasons. The Windyview annex pines are the exception, but the smaller size of these particular timbers would have made overland transportation feasible in the late spring or summer.

Documentary records show that there were no buildings at the 1812 Homestead site when it was surveyed for New York State in 1811, and that a Joseph Moor(e) obtained a license to operate an inn or tavern at the site in 1813 (Tefft 1997). The tree-ring results support this history. Our dates show that the trees for the barn were likely cut in the winter of 1811-1812, allowing the barn to be built in 1812. The trees for the farmhouse, which served as the inn or tavern, were likely cut in the winter of 1812-1813 allowing the structure to be built and opened in 1813. The wood shop was probably added to the property at some later date.

For Windyview Manor, documentary records suggest that a Thomas Stafford bought the property in 1786 , that the house was built $c a$. 1800 , and then subsequently added to and modified during the $19^{\text {th }}$ Century (D. Darrah and M. Bonfey, personal communication, 2008). The tree-ring results support this history as well and suggest that trees for the house were likely cut in the winter of 17981799, allowing the house to be built soon thereafter. The south side of the annex was likely built at the same time and, based on the decay of the timbers, may originally have been partially open or exposed to more water than the main house cellar. The north side of the annex was either added later or rebuilt using trees that were mostly cut in the spring or summer of 1852 .

We have yet to date any buildings older than the 1790s in the town, which is consistent with local history that suggests the original pioneer settlement of William Gilliland was completely destroyed during the American Revolutionary War (Watson 1863). In our results so far we also note that the subsequent $18^{\text {th }}$ and $19^{\text {th }}$ Century redevelopment and growth of Willsboro was marked by an apparent change in wood use, with ash and oak being often found as primary framing timbers in buildings from the 1790 s to 1820 s but almost never thereafter (Figure 5). Gilliland had exported a "vast raft of oak timber" to Quebec in the 1780s (Watson 1863) and it is possible that this timber trade, plus preferential selection of ash and oak for building, had led to local depletion of large trees of these two genera by the early $19^{\text {th }}$ Century.

Hemlock and spruce have only been found in buildings from the 1830s and after (Figure 5). This could be because these were the next-best locally available trees for use as large framing timbers 
after depletion of the preferred hardwoods. It may also reflect these conifers becoming widely and cheaply available as large-scale logging spread in the Adirondacks, with spruce in particular being cut in vast amounts by the 1830s (McMartin 1994). The Boquet River (Figure 1) was one of the waterways along which logs from the Adirondack uplands were floated to saw mills and markets each spring (Keller 1980). In contrast, we have found pine in buildings of all ages (Figure 5), suggesting steady use of this genus for construction in Willsboro despite the reported regional scarcity of pine by the early $19^{\text {th }}$ Century (McMartin 1994).

\section{Development of Willsboro Chronologies}

The results from the 1812 Homestead barn are particularly important because we obtained the same precise date of tree cutting for ash, oak, and pine timbers. Furthermore, our tree-ring dates are entirely consistent with histories of the 1812 Homestead and Windyview Manor based on documentary sources. This gives considerable confidence in the Willsboro chronologies, despite the likely mixing of multiple species (albeit of the same genus) in some chronologies and their crossdating over long distances to the living-tree master chronologies.

During chronology development we found that there were two distinct crossdating populations of both oak and pine among the Willsboro samples. Two of the samples in WHQU1 were identified as probably $Q$. alba whereas nine of the samples in WHQU2 were identified as probably Q. bicolor, and this suggests that the crossdating populations may reflect different species. However, these two species grow respectively in dry and wet habitats (Little 1980; Endinger et al. 2002) and so the factors limiting growth may be just as important as species type to the crossdating signals. For pine it is even more important to consider the factors limiting growth because $P$. strobus, which is the most widespread pine in New York (Little 1970), grows in environments ranging from wetlands to alvars to rich mesophytic woodlands (Edinger et al. 2002). For historical timbers the exact growth setting of the wood is usually unknown and so our crossdating strategy, of identifying to the genus-level and then forming chronologies based on crossdating signals, was adaptive to considerations of both taxa and habitat. This strategy enabled us to combine similar species in chronologies and so maintain good sample depth, and also perhaps to crossdate timbers of less common members of genera that might otherwise be excluded in species-specific chronologies.

The seven chronologies developed from historical timbers in Willsboro will be useful for further dendroarchaeological work in the Champlain Valley and surrounding areas. In particular, the International Tree-Ring Data Bank currently has no historical oak chronologies for northeastern North America north of $c a .43^{\circ} \mathrm{N}$, and no historical ash chronologies at all. These data may also prove useful to dendroclimatic studies in the region for extending and increasing sample depth in the early periods of living tree chronologies.

\section{ACKNOWLEDGMENTS}

We thank Jack Swan, Darren Darrah, Mark Bonfey, and other homeowners in Willsboro for permission to sample at their properties. We gratefully acknowledge Neil Pederson, Carol Griggs, and Ed Cook for providing regional master chronologies that enabled us to crossdate the floating Willsboro chronologies, and Kira Baca, Alexis Wright, Tori Smith, and Amie Staley for help with some sampling and crossdating. Comments by two anonymous reviewers led to substantial improvements to the manuscript.

\section{REFERENCES CITED}

Baillie, M. G. L., 1982. Tree-Ring Dating and Archaeology. The University of Chicago Press, Chicago, Illinois.

Brown, H. P., A. J. Panshin, and C. C. Forsaith, 1949. Textbook of Wood Technology Volume 1: Structure, Identification, Defects, and Uses of the Commercial Woods of the United States. McGraw-Hill Book Company, New York.

Buddington, A. F., and L. Whitcomb, 1941. Geology of the Willsboro Quadrangle, New York. New York State Museum Bulletin 325.

Edinger, G. J., D. J. Evans, S. Gebauer, T. G. Howard, D. M. Hunt, and A. M. Olivero, Eds., 2002. Ecological Communities of New York State, 2nd ed. New York Natural Heritage Program, Albany, NY. 
Glitzenstein, J. S., C. D. Canham, M. J. McDonnell, and D. R. Streng, 1990. Effects of environment and land-use history on upland forests of the Cary Arboretum, Hudson Valley, New York. Bulletin of the Torrey Botanical Club 117:106-122.

Grissino-Mayer, H. D., 2001. Evaluating crossdating accuracy: A manual and tutorial for the computer program COFECHA. Tree-Ring Research 57:205-221. , 2009. An introduction to dendroarchaeology in the southeastern United States. Tree-Ring Research 65:5-10.

Harvey, E., 2012. Dendrochronology: A Status Report for the Eastern United States. M.S. thesis, Clemson University and the College of Charleston, Clemson, South Carolina.

Hoadley, R. B., 1990. Identifying Wood: Accurate Results with Simple Tools. The Taunton Press, Newtown, Connecticut.

Holmes, R. L., 1983. Computer-assisted quality control in treering data and measurement. Tree-Ring Bulletin 43:69-78.

Keller, J. E., 1980. Adirondack Wilderness: A Story of Man and Nature. Syracuse University Press, Syracuse, NY.

Little, E. L. Jr., 1971. Atlas of United States trees, Volume 1, Conifers and Important Hardwoods. US Department of Agriculture Miscellaneous Publication 1146, 9 pp., 200 maps. , 1980. National Audubon Society Field Guide to North American Trees: Eastern Region. Alfred A. Knopf, Chanticleer Press edition, New York.

McMartin, B., 1994. The Great Forest of the Adirondacks. North Country Books, Utica, NY.

Palmer, P. S., 1983. History of Lake Champlain. Harbor Hill Books, Harrison, NY.

Pederson, N., A. R. Bell, E. R. Cook, U. Lall, N. Devineni, R. Seager, K. Eggleston, and K. P. Vranes, 2013. Is an epic pluvial masking the water insecurity of the greater New York City region? Journal of Climate 26:1339-1354.

Querrec, L., L. Filion, R. Auger, and D. Arseneault, 2009. Treering analysis of white cedar (Thuja occidentalis L.) archaeological and historical wood in Québec City (Québec, Canada). Dendrochronologica 27:199-212.

Robichaud, A., and C. P. Laroque, 2008. Dendroarchaeology in southwestern Nova Scotia and the construction of a regional red spruce chronology. Tree-Ring Research 64:17-25.

Sayre, R., P. Comer, H. Warner, and J. Cress, 2009. A New Map of Standardized Terrestrial Ecosystems of the Conterminous United States. US Geological Survey Professional Paper 1768.

Smith, B. E., P. L. Marks, and S. Gardescu, 1993. Two hundred years of forest cover changes in Tompkins County, New York. Bulletin of the Torrey Botanical Club 120:229-247.

Stahle, D. W., 1979. Tree-ring dating of historic buildings in Arkansas. Tree-Ring Bulletin 39:1-28.

Stokes, M. A., and T. L. Smiley, 1968. An Introduction to TreeRing Dating. The University of Arizona Press, Tucson, AZ.

Tefft, T., 1997. The 1812 Homestead: Local History, Site History, and Local Statistics. 1812 Homestead Educational Foundation, Willsboro, NY.

Watson, W. C., 1863. Pioneer History of the Champlain Valley; Being an Account of the Settlement of the Town of Willsborough by William Gilliland, Together With His Journal and Other Papers, and A Memoir, and Historical and Illustrative Notes. J. Munsell, Albany, New York.

Received 5 November 2012; accepted 10 April 2014. 